\title{
Dráma Jiřího Mahena Janošík v slovensko- českých a európskych súvislostiach
}

\author{
Renáta Bojničanová (Bratislava)
}

\begin{abstract}
Abstrakt
Štúdia sa venuje fenoménu „zbojníckej drámy“ v slovenskej a českej literatúre 19. a začiatku 20. storočia s osobitým zretel'om na špecifické spoločenské okolnosti, ktoré podmienili jej vývoj a recepciu. Vysvetlujú sa súvislosti slovenských a českých diel s európskou romantickou drámou a sprostredkovane až s barokovou „zbojníckou komédiou", dramatickým podžánrom, ktorý sa sformoval v španielskej literatúre 17. storočia. Sleduje sa vývoj slovenských a českých drám so zbojníckou tematikou od predromantických po novoromantické podoby, ktorých príkladom je dráma Janošík (1910) českého autora Jiřího Mahena. Naznačujú sa niektoré inšpiračné zdroje tohto Mahenovho diela, smerujúce k romantickej západoeurópskej dráme a sprostredkovane až k španielskej barokovej komédii. Zároveň upozorňujeme na diskontinuitu vývoja slovenskej zbojníckej drámy a určujeme miesto, ktoré v jej kontexte zaujíma Mahenov Janošík.
\end{abstract}

\section{Klúčové slová}

zbojnícka romantická dráma; španielska „zbojnícka komédia“; Juraj Jánošík; Jiří Mahen; novoromantizmus

\section{Abstract \\ Drama by Jiří Mahen Janošík in the Slovak-Czech and European context}

This study is dedicated to the phenomenon of "Bandit drama" in Slovak and Czech literature of the $19^{\text {th }}$ and early $20^{\text {th }}$ century, with special attention to the social conditions that influenced its development and reception. In this paper we explain the relationship of Slovak and Czech dramatic works with European romantic theatre, and indirectly with the baroque "Bandit comedy", subgenre formed in Spanish literature in the $17^{\text {th }}$ century. We follow the development of the drama with the theme of bandits from pre-romantic to neo-romantic versions, whose example is the drama Janošik (1910) of the Czech autor Jiř Mahen. We suggest some sources of inspiration for this drama of Mahen, that point to the romantic drama and by extension to the baroque comedy. At the same time we warn of the discontinuity of the evolution of the Slovak Bandit drama and we indicate the place that in its context corresponds to Mahen's Janošik.

\section{Key words}

romantic drama of bandits; Spanish "bandit comedy"; Juraj Jánošík; Jiř̌ Mahen; neo-romanticism 


\section{Úvod}

V tejto štúdii sa sústred’ujeme na drámu Jiřího Mahena Janošík (1910), ktorú hodnotíme ako dielo svojské, ale zároveň „typizované“, tvoriace súčast̉ celého radu drám komponovaných podla istého stereotypného modelu s dlhou tradíciou. Jeho kontextualizáciu určujeme na podklade dvoch súbežných línií: rekapitulujeme zásadné okamihy vývoja zbojníckej drámy u slovenských autorov 19. storočia, ktorých možno považovat za Mahenových predchodcov, hoci autor na nich vedome nenadviazal, a zároveň sledujeme paralelný vývoj „zbojníckej drámy“ ako špecifického dramatického podžánru v európskom kontexte. Upozorňujeme na spoločné zdroje inšpirácie „zbojníckej drámy“, ktoré treba hladat v nemeckom a francúzskom romantizme a ešte hlbšie v španielskej barokovej „zbojníckej komédii“. V súvislosti s Mahenovým Janošikom sa zamýšlame aj nad základnou otázkou Mahenovej motivácie k záujmu o túto slovenskú národnú tému a naznačujeme, v čom tkvie jej pozitívna recepcia a úspešnost́.

\section{Slovenská romantická zbojnícka dráma v európskych súvislostiach}

Do slovenskej dramatickej tvorby vstúpila zbojnícka tematika $\mathrm{v}$ dvadsiatych rokoch 19. storočia v spracovaní Štefana Petruša (1783-1831), ktorý v roku 1823 napísal „historickú činohru na spusob komedie složenú" v piatich dejstvách, nazvanú Rajnoha, zbojnícky hajtman aneb Začátkové černohrončánských handlov. Dielo má v kontexte slovenskej literatúry mimoriadny význam, pretože, ako tvrdí Michal Babiak, je „prvou slovenskou novodobou činohrou" ${ }^{1}$ vôbec. Napriek tomuto významnému prvenstvu zostával Štefan Petruš dlhodobo nepovšimnutý a jeho literárne zásluhy verejnost’ prakticky nepoznala². Petrušov literárny počin je v predštúrovskom období výnimočný aj preto, že „objavitel'mi“ zbojníka ako prototypickej literárnej postavy sú až romantici štúrovskej generácie, ktorí sa sústredili na historickú osobnost' Juraja Jánošíka, vyňali ju z pokladnice ludovej slovesnosti a zvečnili ju predovšetkým v početných básnických skladbách. V dramatickej tvorbe sa Jánošík objavil v štyridsiatych rokoch 19. storočia vd’aka Eduardovi Miloslavovi Škultétymu (1825-1891) a Samuelovi Ormisovi-Zdychavskému (1824-1875). Obe „jánošíkovské“ hry, podobne ako Petrušova činohra, neprenikli na verejnost’ a, pokial’ je nám známe, neboli divadelne inscenované a ani knižne či časopisecky vydané. Ormisov Jánošík, ktorého vznik sa datuje do roku 1847, sa dočkal vydania až roku 1919 v českom nakladatel'stve Přemysla Plačeka v edícii Knižnica československá, na čom edičnú zásluhu má F. Frýdecký. Mimochodom, podla zistenia A. Zelenkovej a M. Pokorného ${ }^{3}$, v pacovskom vydavatel'stve P. Plačeka vyšlo aj prvé slovenské vydanie Mahenovej drámy (r. 1920), ako aj jej

1 BABIAK, Michal: Preromantická dráma Štefana Petruša. In: PETRUŠ, Štefan: Rajnoha, zbojnícky hajtman aneb Začátkové černohrončárských handlov. Bratislava: Národné divadelné centrum, 1998, s. 213.

2 O sústavnom zamlčiavaní a ignorovaní Petrušovho diela píše Michal Babiak, tamže, s. 213-225. Knižného vydania sa činohra Rajnoha... dočkala až v roku 1998, pri 175. výročí od svojho vzniku (vyššie citovaná publikácia).

3 ZELENKOVÁ, Anna - POKORNÝ, Milan: Knižni slovacika v českých nakladatelstvích 1918-1925. In: POSPÍ- 
neskoršie reedície (r. 1923). V šesṫdesiatych rokoch spracoval jánošíkovský námet Jonáš Záborský (Jánošikova večera. Činohra v štyroch dejstvách s úzadím historickým, 1867), jeho hra vyšla ako príloha časopisu Sokol a dostala sa aj na divadelnú scénu vd’aka ochotníckemu súboru v Liptovskom Trnovci.

Vo všetkých spomínaných divadelných hrách zo štyridsiatych až šestdesiatych rokov 19. storočia autori uplatnili rovnaký umelecký postup. Vybrali si postavu historicky reálneho zbojníka domáceho pôvodu a využili vlastnú fantáziu na vybudovanie prítažlivého dramatického deja. Jánošíkovské motívy čerpali zo slovenskej ludovej tradície, ale použili aj „nedomáce“ literárne motívy a v rozličnom pomere ich skombinovali. Spoločné pre tieto romantické podoby zbojníckej drámy je, že Jánošík je v nich zobrazený v pozitívnom duchu, je hrdinom obdareným obdivuhodnými vlastnostami (odvaha, zmysel pre spravodlivost', vyznávanie slobody ako najvyššej hodnoty, dôvtip atd'), bojovníkom za spravodlivost’ a obrancom utláčaných, čo typologicky korešponduje s typom „šlachetného zbojníka“" . K zbojníčeniu ho dohnali väčšinou tragické okolnosti v osobnom živote, cez ktoré pochopil, že sa musí postavit za práva utláčaných a „bojovat“ za ich obranu. Takouto typológiou hrdinu autori nadväzujú na vzor, ktorý vytvoril Štefan Petruš na príklade zbojníka Rajnohu ${ }^{5}$.

Ďalšiu etapu v spracovaní zbojníckeho (konkrétne jánošíkovského) námetu, v ktorom je prítomné už aj preukázatel’né česko-slovenské prepojenie, situujeme do osemdesiatych rokov 19. storočia. V roku 1880 slovenský Jánošík „prekročil hranice“ a predstavil sa v Čechách v dielach dvoch slovenských autorov, v smutnohre Jánoši $k^{6}$ Miška Vrbu-Skačanského (1845-1882) a v básnickej zbierke Spevy Jána Bottu, obsahujúcej elegickú skladbu Smrt' Jánošíkova. Tieto dve diela sú rozdielne nielen druhovo, ale aj estetickým spracovaním. Zatial' čo Bottova Smrt'Jánošíkova je spracovaná v duchu rešpektovania domácich zdrojov inšpirácie (l'udová slovesnost') a vznešenej funkcie literatúry (vyjadrenie závažných národných posolstiev), a nepochybne patrí do pokladnice vrcholných diel slovenskej „vysokej“ romantickej poézie, Skačanského Jánošik vybočuje z programových línií oficiálneho smerovania slovenskej romantickej literatúry. Neprekvapuje preto, že aj umelecké kvality jeho diela boli od začiatku spochybňované: dobová kritika (S. Hurban-Vajanský, J. Škultéty) mu ako nedostatok vyčítala, ak zhrnieme to najdôležitejšie, estetickú „poklesnutost“", duchovnú prázdnotu a nasmerovanie na populárny dobrodružno-milostný typ literatúry. Poplatnost’ vzorom „poklesnutej“ populárnej literatúry sa môže javit’ ako estetická nedokonalost', ale pri zarad’ovaní do širších kultúrnych kontextov netreba tomuto estetickému kritériu pripisovat jednoznačne negatívny význam. Potrebný nadhlad prejavila vo svojej

ŠIL, Ivo - ZELENKA, Miloš (eds.): Česko-slovenské vztahy, Evropa a svět. Brno: Ústav slavistiky FF MU, 2004, s. 132, 134.

4 Protikladom tohto typu je „zbojník-zloduch“, v literatúre (umeleckej, ale aj odbornej) označovaný najčastejšie ako „lupič“, „lúpežník“, ale aj „živáň“ a i.

5 Na okraj podotýkame, že Rajnoha so svojimi zbojníckymi kumpánmi sa objavuje aj v divadelnej hre Jána Chalupku Kocúrkovo (1930), ale nie ako protagonista, iba ako epizodická postava. Ked’že ide iba o „zbojnícky výstup“ (scéna stretnutia zbojníkov so študentmi v lese v druhom akte), hru nepovažujeme za súčast dejín „zbojníckej drámy“.

6 SKAČANSKÝ, Michal: Jánošik, smutnohra v piatich jednaniach. Praha: nakladatel' a vydavatel’ Franko Karabina, v komisii knihkupectva Edvarda Grégra a Ferdinanda Dattla, 1880. 
interpretácii Joanna Goszczyńska, autorka komplexnej monografie Mit Janosika w folklorze a literaturze slowiackiej XIX wieku ${ }^{7}$, v ktorej velmi zasvätene analyzuje vývoj jánošíkovského mýtu 19. storočia v dráme v usúvztažnení na jeho podoby v populárnom románe ${ }^{8}$. Pol'ská slavistka a slovakistka konštatuje spochybnitel’nú umeleckú kvalitu Skačanského diela, ale zároveň naznačuje zaujímavé medziliterárne súvislosti. V nadväznosti na českú literatúru upozorňuje na to, že Jánošík je v Skačanského spracovaní „blǐšš tajomnému romantickému zbojnikovi, ,strašnému lesnému pánovi` z Máchovho Mája, než ludovému zbojnikovi a jeho obrazu v ludovej slovesnosti“ “. ${ }^{9}$ Okrem toho, Skačanského Jánošika dáva do súvisu aj s dielami nemeckého romantizmu, konkrétne so Schillerovou drámou Zbojníci (Die Räuber, 1781) a s románom Rinaldo Rinaldini (1799) Christiana Augusta Vulpia (1762-1827). Súvislosti vidí, napríklad, v tom, že podobne ako v Rinaldovom prípade, Jánošík je urodzeného pôvodu, ale nevie o tom a dozvedá sa pravdu až v čase svojej dospelosti, pri vstupe do družiny prehlasuje heslo neprelievat krv, má bohatý citový život a lahko sa necháva fascinovat ženskými pôvabmi. Na okraj pripomíname, že všetky tieto motívy zo života zbojníckeho hrdinu nachádzame už v starobylejších európskych dielach než v Schillerovi (vysvetlenie podávame nižšie), ako aj (výberovo) v starších slovenských spracovaniach. Joanna Goszczyńska zhrňujúco hodnotí Skačanského dramatický text ako dielo „pseudoromanticke" a ako "prvý a najvýraznejši priklad populárnej literatúry, v ktorom bol mýtus o Jánošikovi spracovaný podla Schillerovho vzoru. "10

Michal Vrba-Skačanský je teda súčastou radu autorov zbojníckych drám, ktorých umelecké postupy tkveli v imitácii overeného modelu zbojníckej drámy a vo volnom využití jej konštitučných prvkov. Hovoríme o rade autorov, pretože Skačanského predstihli už vyššie spomínaní slovenskí autori (každý z nich v takej či onakej miere využil tento literárny postup), a zároveň, takáto „imitačná“ tendencia tvorby je pomerne hojne zastúpená aj v celoeurópskom rozmere. Joanna Goszczyńska, citujúc prácu pol’ského bádatela Tadeusza Żabskeho" ${ }^{11}$ sa zmieňuje o d’alšom „vzore“ populárnej drámy, ktorým je divadelná hra nemeckého autora Heinricha Zschokkeho (1771-1848) Abellino, velký zbojnik (Abällino, der große Bandit, 1793). Podla Żabskeho, táto hra „významne ovplyvnila vývoj zbojnickej drámy“, hoci jej vplyv sa nemohol „z historických dôvodov na územi Slovenska prejavovat", pretože „pred rokom 1918 neexistovalo slovenské profesionálne divadlo a viaceré ochotnicke súbory boli zamerané najmä na slovenský a český národno-buditelský repertoär ${ }^{\text {“ }} .{ }^{12}$ Ide o d’alšiu

7 GOSZCZYŃSKA, Joanna: Mit Janosika w folklorze a literaturze slowiackiej XIX wieku. Warszawa: Uniwersytet Warszawski, 2001. V tejto štúdii citujeme autorku podla slovenskej verzie monografie z roku 2003.

8 Skačanského Jánošíka porovnáva so súdobými populárnymi (,poklesnutými“) zbojníckymi románmi slovenských autorov P. Beblavého, G. Maršalla-Petrovského.

9 GOSZCZYŃSKA, Joanna: Mýtus o Jánošikovi vo folklóre a slovenskej literatúre 19. storočia. Bratislava: Juga, 2003, s. 146.

10 Tamže, s. 143.

11 ŻABSKI, Tadeusz: Proza jarmarczna XIX wieku: próba systematyki gatunkowej. Wrocław: Wydawnictvo Uniwersytetu Wrocławskiego, 1993.

12 ŻABSKI, citované podla GOSZCZYŃSKA, Joanna: Op. cit., s. 143. Na okraj k citovanej myšlienke podotýkame, že fakt, že cudzojazyčné drámy neboli na Slovensku prekladané a uvádzané v divadlách, nepovažujeme za prekážku, ktorá by slovenský kultúrny kontext izolovala od kontextu európskeho, pretože 
drámu v štýle imitácie Schillerových Zbojnikov, ktorá pôsobila ako „vzor“ predovšetkým v nemeckom prostredí.

Schillerov vzor bol, samozrejme, známy a nasledovaný aj v románskom kultúrnom priestore. K jeho popularite vo francúzskom prostredí sa zaslúžil Jean Henri Ferdinand Lamartelière (1761-1830), dramaturg a autor prvých prekladov a adaptácií Schillerových drám do francúzštiny. Lamartelière, mimochodom, preložil do francúzštiny aj Zschokkeho Abellina (preklad vznikol roku 1799).

Príklad nasledovníka Schillerovho vzoru nachádzame aj v španielskej literatúre, a to v osobe Carlosa Coellu y Pacheca (1850-1888). Tento dnes málo známy dramatik a prozaik napísal veršovanú zbojnícku drámu s názvom Roque Guinart, publikovanú a uvedenú na scénu roku 1874. Na súvislosti medzi Coellovým Roca Guinartom a Schillerovými Zbojnikmi upozorňuje vo svojej komparatívnej práci Rosa Cardinaleová13, nazývajúc Coellu y Pacheca nepriamo „Schillerovým imitátorom“. Je zjavné, že autor vel'mi podobne stvárnil charaktery postáv a stanovil rodinné a citové vztahy ${ }^{14}$, ktoré šlachtického syna dobrého srdca (Karla Moora / Roca Guinarta) doviedli k zbojníctvu. Netreba však zabúdat', že Coello y Pacheco sa nemusel opierat iba o Schillera, ale mal k dispozícii domáce a ovel’a starobylejšie literárne vzory. Nielenže katalánskeho zbojníka Perota de Rocaguinardu objavil pre literatúru už Miguel de Cervantes (objavuje sa v románe Don Quijote, 1615, 2. čast', LX a LXI. kapitola), ale tvorcami prvých európskych divadelných hier o zbojníkoch boli práve španielski dramatici zlatého veku, hladajúci inšpiráciu neraz v životných osudoch katalánskych zbojníkov. Ako potvrdzujú viacerí odborníci ${ }^{15}$, „zbojnícka komédia“ sa konštituovala ako samostatný podžáner v španielskej literatúre 17. storočia a jej počiatky treba hladat’ v komédii o katalánskom zbojníkovi Antoniovi Rocovi $^{16}$, ktorú v roku 1603 napísal vel’ký dramatik španielskeho zlatého veku Lope de Vega (1562-1635). K rozkvetu „zbojníckej komédie“ prispeli mnohí iní dramatici, spomedzi nich najznámejšími sú Tirso de Molina, Luis Vélez de Guevara, Francisco de Rojas Zorrilla, Antonio Coello y Ochoa, Antonio Mira de Amescua, či Pedro Calderón de la Barca. Ich mená a divadelné hry boli prekladané a uvádzané na scénu v celej Európe, preto nemožno považovat’ za náhodu, že mnohé motívy typické pre romantické spracovania

medziliterárne prúdenie sa realizuje aj inými cestami, ako je priamy dotyk literárneho diela s čitatel’ským alebo diváckym publikom.

13 CARDINALE, Rosa: El bandolero español entre la leyenda y la vida real. Calas en configuraciones del bandolero en textos paradigmáticos de los siglos XVII-XX. Madrid: Editorial Verbum, 2009, s. 136-160.

14 Postavy a ich povahové črty a konanie sa vyvíja podla rovnakých vzorcov a nachádzame medzi nimi zjavné paralely: gróf z Vilasaru = Maximilian Moor; Jaime de Moncada, premenený na zbojníka Roca Guinarta = Karl Moor; Jaimeho brat Ramón = Franz Moor; Eulalia = Amalia atd'.

15 DIXON, Víctor: Un género en germen: Antonio Roca de Lope y la comedia de bandoleros. In: CLOSE, Anthony J. - FERNÁNDEZ VALES, Sandra María (koord.): Edad de Oro cantabrigense: Actas del VII Congreso de Asociación Internacional de Hispanistas del Siglo de Oro. Madrid-Franfurkt: Iberoamericana Editorial Vervuert, 2006, s. 189-194; GARCÍA GONZÁLEZ, Almudena: El bandolero histórico como personaje de comedia en Lope. In: Anuario Lope de Vega. Texto, literatura, cultura. XVIII. 2012, s. 64.

16 Lope de Vega napísal viacero zbojníckych drám, medzi inými aj hru o už spomínanom Roca Guinartovi, ktorej text sa však nezachoval. V. Dixon (2006, s. 189-194) za najdôležitejšiu považuje hru Antonio Roca, pretože v nej Lope anticipoval mnohé motívy, ktoré sa neskôr stali charakteristické pre „zbojnícku komédiu“ zlatého veku, a vytvoril archetypy hrdinov typických pre tento dramatický podžáner. 
majú predchodcov v divadelných hrách španielskeho baroka. Práve v týchto hrách, ale aj v literárno-folklórnych predlohách, ktoré ich predchádzali, nachádzame celú škálu topických motívov a situácií, opakujúcich sa v romantických zbojníckych drámach, napríklad obraz zbojníka ako „šlachetného zločinca“, vyšší spoločenský pôvod alebo tajomný pôvod zbojníka, zbojník - zbehnutý seminarista, hrdina ovládaný osudom, zbojník odmietajúci násilie, začatie zbojníckej dráhy proti vlastnej vôli, úloha zradcu pri páde zbojníka, rodinné pomsty, význam osobnej cti, dobrovol'né vzdanie sa nepriatel'ovi, dobrovolné prijatie smrti, odmietnutie milosti na popravisku a rozsiahlu škálu lúbostných zápletiek v živote zbojníka. Nielen jednotlivé motívy, ale celé schémy zbojníkovho života a konania sa stali typickou a topickou výbavou zbojníckych komédií a neskôr preromantických a romantických drám. Samozrejme, citovaný autor Carlos Coello y Pacheco nie je žiadnym ojedinelým zjavom, ale je iba jedným z dlhého radu predstavitelov španielskej zbojníckej drámy 19. storočia ${ }^{17}$, vychádzajúcej z domácej tradície, ale svojou náplňou zákonite zhodnej s drámami nemeckej, francúzskej a inej národnej proveniencie.

Nemožno preto celkom jednoznačne prijat tvrdenie T. Żabskeho, že Schiller predstavuje „pravzor“ európskej zbojníckej drámy a že predznačuje jej „základné druhové charakteristiky“. ${ }^{18}$ Je pravda, že F. Schiller mal nepochybne zásadný vplyv na romantické spracovania v európskych literatúrach, ale časovo ho predstihli španielski dramatici 16.-17. storočia a práve oni vytvorili „pravzor“ základných druhových charakteristík zbojníckeho dramatického podžánru („zbojníckej komédie“), ktorý neskôr prevzali preromantickí a romantickí autori.

Zároveň si treba uvedomit', že významným ohnivkom vo vývoji a etablovaní romantickej zbojníckej drámy bolo, okrem Schillerových Zbojnikov, aj dramatické dielo Victora Huga, a v súvislosti s tematikou vydedenca spoločnosti - zbojníka, predovšetkým s tragédiou Hernani (1830), ktorej protagonista bol imitovaný súdobými francúzskymi autormi a opakovane vytváraný v iných obmenách samotným Victorom Hugom. Je známe, že dielo Victora Huga malo mimoriadny vplyv na formovanie európskej romantickej drámy a Hugova dramatika má vela styčných bodov práve so španielskou barokovou „komédiou“, ktorá je pôvodnou kolískou európskej zbojníckej drámy.

\section{Jánošík v českej dramatickej tvorbe: Jiří Mahen}

Začiatkom 20. storočia sa k slovenským divadelným hrám o Jánošíkovi pridružujú české spracovania. Roku 1910 knižne vyšla dráma Jiřího Mahena Janošik, tragedie o pěti dějstvích, roku 1907 vznikla knižná dráma Jánošik Karela V. Prokopa a s časovým odstupom histo-

17 Medzi najúspešnejších dramatikov v tejto línii tvorby patrili José María Guiérrez de Alba (1822-1897), ktorý zožal mimoriadny úspech s drámou Diego Corrientes alebo Šlachetný zbojnik (Diego Corrientes o El bandido generoso). Od jej premiéry v roku 1848 bola neustále uvádzaná na scénu, reeditovaná a rozširovaná. Guitiérrez de Alba, ale aj iní autori prevzali túto predlohu a v priebehu pätdesiatych a šestdesiatych rokoch 19. storočia písali jej nové verzie, dalšie „dramatické diely“ na pokračovanie a imitácie, ako aj adaptácie od románových podôb. Medzi predstavitelov tohto typu drámy patria Enrique Zumel, Luis Mejías y Escassy a mnohí d’alší, v panoráme španielskej literatúry z hladiska významu „okrajoví“, autori. 
rická dráma rovnakého názvu autorky Františky Svobodovej-Goldmannovej. Divadelná hra Jiřího Mahena bola spomedzi týchto diel najúspešnejšia. V tom istom roku 1910 sa konala jej premiéra v pražskom Národnom divadle (30. 9. 1910) a v brnianskom Národnom divadle (21. 12. 1910) a na oboch scénach bola publikom kladne prijatá. Po mnohom márnom úsilí slovenských autorov sa teda objavil autor spoza hraníc a hned’ prvým pokusom triumfoval na významných divadelných scénach.

Ako vyplýva z preložených faktov, začiatkom 20. storočia nastáva výrazný posun v dejinách pôvodne slovenskej zbojníckej drámy: na jednej strane prichádza k jej rozšíreniu do česko-slovenského priestoru a zároveň k prvým prejavom jej životaschopnosti a pozitívnej recepcie.

Nastáva tu logická otázka, z akých podnetov sa jánošíkovskej témy chopil čáslavský rodák, pražský študent, český intelektuál usadený na Morave, u ktorého by sme mimoriadny záujem o slovenskú zbojnícku látku nepredpokladali. Domnievame sa, že tento záujem je podmienený viacerými faktormi, z ktorých za najrukolapnejšie možno považovat: 1. revolučné naladenie a sociálne cítenie autora, na vyjadrenie ktorých ponúkala zbojnícka látka vhodnú symboliku; 2. autorov pomerne čerstvý dojem zo Slovenska a 3. autorove predchádzajúce pozitívne skúsenosti s literárnym spracovaním zbojníckej tematiky a jeho dávnejší záujem o ňu ako o literárnu látku. V nasledujúcej časti práce v krátkosti vysvetlíme tieto tri podmieňujúce faktory.

Určitú symboliku zbojníckeho hrdinu možno pozorovat’ už v umeleckom mene, ktoré si Antonín Vančura zvolil, aspoň podl’a toho, ako túto vol’bu vysvetluje Štěpán Vlašín, ked' píše o Zolovom Toussaintovi Maheuovi ako o hrdinovi „usilujicím se o spravedlnost a hynoucím jako obět sociálního útlaku“, ktorý „byl blizký srdci mladého bouřliváka“. ${ }^{19}$ Práve tieto vlastnosti a postoje, akými sú „cit pre spravodlivosṫ a odhodlanie bojovat za ňu a obetovat sa“, Mahen aplikoval na postavu Jánošíka, pričom boj o sociálnu spravodlivost̉ sa v jeho prípade spája s ideou boja za národnú slobodu. O tom, že autor tieto ideové obsahy vo svojej hre prepojil úmyselne, vypovedá často citované motto-venovanie z úvodu drámy: „Tomu Slovensku, těm Jánošikovým regimentům, jež za volnost národa se biji, za svobodu jeho a pravdu v něm - tuto hru posvěcuje autor. “20 Na postavu Jánošíka sa idea boja za slobodu a spravodlivosț viaže trojnásobne: je bojovníkom za spravodlivost’ osobnú, sociálnu a národnú. V Mahenovom spracovaní, ako aj v predchádzajúcich slovenských dramatických spracovaniach, pramení Jánošíkovo prebudenie spoločenskej „angažovanosti“ zo zážitku osobnej ujmy (motív ubitia otca, motív lúbostného sklamania). Cez pocit osobnej nespravodlivosti začína hrdina vnímat aj nespravodlivost’ sociálnu a národnú: panskou svojvôlou a vykoristovaním netrpí iba on, ale celá komunita (rodná dedina) a d’alej celý národ.

Jiří Mahen pocituje istú vnútornú podobnost’ so zbojníckym hrdinom. S vlastným hlbokým a včasne prebudeným sociálnym cítením, ako aj o dôvodoch, ktoré ho podnecovali, sa opakovane zdôveruje v osobných konfesiách. V reflexii Moje mládí z roku

19 VLAŠÍN, Štěpán: Doslov. In: MAHEN, Jiří: Jánošík, Ulička odvahy, Nasreddin. Praha: Státní nakladatelství krásné literatury a umění, 1962, s. 303.

20 MAHEN, Jiří: Jánošik. In: MAHEN, Jiří: Jánošík, Ulička odvahy, Nasreddin. Praha: Státní nakladatelství krásné literatury a umění, 1962, s. 8. 
1919 píše: „Sociálni cit byl ve mně probuzen velmi brzy. Prostě tím, že mưj otec šel z úpadku do úpadku, ačkoli měl kdysi slušné jmění... Odtud $i$ moje sociální sympatie a můj pozdějši anarchismus..." ${ }^{21}$ Podobne ako u zbojníckeho hrdinu, Mahenovo pôvodne osobne motivované sociálne cítenie prerástlo do schopnosti solidarizovat sa s utrpením širších spoločenských skupín spôsobeným rozličnými formami spoločenského útlaku, teda aj útlaku národného. Na inom mieste svojich osobných reflexií Mahen spomína: „U Jánošika šlo o věc časovou, jejim vzorem byly události v Černove “22, čo znamená, že vysvetluje svoju drámu ako istý druh protestného ohlasu na masakru v Černovej, v ktorej národný útlak prejavil s mimoriadnou brutalitou. Dielo síce nenapísal v aktuálnom čase týchto udalostí, ale s vyše dvojročným odstupom (október 1907 - jún až august 1910), aktuálne však na ne zareagoval básňou Černouská masakra ${ }^{23}$. Z citovanej myšlienky vyplýva, že autor chápal svoje dielo ako v istom zmysle „príležitostné“ a samozrejme, potvrdzuje ňou záujem o aktuálne dianie na Slovensku.

Znalci hovoria o Mahenových sympatiách k Slovensku, hoci ich názory na hĺbku poznania „skutočného“ Slovenska sa líšia. Štěpán Vlašín ${ }^{24}$ píše, že „východnú zem“ („země na východ“) Mahen osobne objavil vd’aka potulkám po západnom Slovensku hned' po svojom príchode na Moravu v roku 1907, podla tvrdení iných odborníkov ${ }^{25}$ Slovensko osobne navštívil a spoznal až ovel'a neskôr. Nech už Mahen Slovensko „objavil“ kedykolvek, za dôležité považujeme poznanie jeho vztahu k tejto krajine, a tu sa možno opriet priamo o jeho slová. Z nich vyplýva, že Slovensko vnímal ako krajinu nespútanú, tajomnú až nebezpečnú, do ktorej „prý se smělo jenom opatrně, čiže v istom zmysle ako krajinu „divú“, „prírodnú“ a exotickú. Silným dojmom naňho zapôsobili l’udia, ktorí sa mu javili ako bezprostrední, vitálni, „po svém energičtí, po svém dobři i ukrutní, po svém prosti“ ${ }^{26}$. „Životodárná prostota“27 sa u Mahena javí ako dominantný dojem zo Slovenska a uplatnila sa aj ako estetická kategória v spracovaní jánošíkovskej tematiky. Prilnutie k prostote je vyjadrením „záškodníctva voči avantgarde“ a opozície voči preintelektualizovanej českej kultúre mestského typu, od ktorej sa Mahen po príchode na Moravu odklonil. Samozrejme, obraz Slováka ako človeka „energického, dobrého a zároveň krutého, svojím spôsobom prostého" sa pretavil aj do Janošika.

21 MAHEN, Jiří: Moje mládi (1919). Citované podla MAHEN, Jiří: Za oponou uměni a života. Praha: Československý spisovatel, 1961, s. 10.

22 MAHEN, Jiří: $O$ „vedlejšich“ knižkách (1928-1929). Citované podla MAHEN, Jiř̌í: Tamže, s. 91.

23 Je všeobecne známe, že tragédia v Černovej vzbudila vlnu medzinárodnej solidarity so slovenským národom, zvlášt zo strany českých politikov a intelektuálov, a jej dozvuky trvali niekolko rokov, až po finálne vysvätenie černovského kostola Andrejom Hlinkom roku 1910. V tomto roku vyšiel Mahenov Janošik knižne a predstavil sa na významných českých divadelných scénach. Nastáva otázka, či sú tieto časové zhody náhodné.

24 VLAŠíN, Štěpán: Doslov. In: MAHEN, Jiří: Jánošík, Ulička odvahy, Nasreddin. Praha: Státní nakladatelství krásné literatury a umění, 1962, s. 304.

25 Pozri TVRDOŇ, Jozef: Jiřr Mahen a Slovensko. In: Krásy Slovenska 37, 1960, č. 9, s. 343.

26 MAHEN, Jiř́i: Proč Janošik? (1931). Citované podla MAHEN, Jiř́i: Za oponou uměni a života. (Janošík), Praha: Československý spisovatel, 1961, s. 88.

27 Tamže, s. 88. 
Napokon, ako tretí faktor Mahenovho zblíženia s jánošíkovskou tradíciou sme uviedli autorov predchádzajúci záujem o zbojnícku tematiku a jeho pozitívne skúsenosti s jej literárnym spracovaním. Tu máme na mysli jednoaktovku Juanův konec (1905), ktorá je prvou Mahenovou knižne vydanou a zároveň v inscenovanej forme publikom úspešne prijatou dramatickou prácou ${ }^{28}$. Toto dielko je v súvislosti so zbojníckou tematikou a s Janošikom zaujímavé preto, že v jeho kompozícii sa prejavujú autorove vedomosti v oblasti európskej romantickej zbojníckej drámy. Svedčí o tom typológia dramatických postáv (protagonista: zbojník - lupič, zvodca - donjuan, d’alšie postavy: hrbáč, spevák), dramatický konflikt (tajomný lúbostný motív, stávka, pomsta, „božia“ pomsta), vytvorenie prostredia a evokácia atmosféry (hlboký les, krčma, noc, búrka), ako aj viaceré divadelné „efekty“ (kostým Dona Juana typický pre komédiu „plášta a meča“). Vel’mi pozoruhodné je využitie španielskych reálií a postava zbojníka (lupiča, zloducha) z obdobia napoleonských vojen. Túto dramatickú prvotinu možno celkovo považovat’ za prejav sčítanosti autora v matérii romantického spracovania zbojníckej tematiky podla tradícií západoeurópskej romantickej drámy ${ }^{29}$, pričom svoje znalosti z tejto oblasti autor mohol využit a nepochybne využil aj v Janošikovi.

Ďalší dôkaz o tom, že Mahenovi boli romantické spracovania zbojníckej tematiky známe a blízke, nachádzame v jeho záujme o tvorbu K. H. Máchu. Roku 1910 Mahen dovŕšil štúdiu-prednášku Máchova poezie a jeji význam, v ktorej vyjadruje obdiv k skladbe Máj. Cíti sa spriaznený s osudom jej protagonistu, vidiac v ňom obraz revoltujúcej básnikovej duše: „Vilém - strašný lesưv pán -, tot’ ovšem básnik sám, tot’ básnikova duše, hledajici ve světe svou vlast, svou hroznou vinu, své smiřeni s bohem i lidmi kolem, tot’ velký výkrìk básnického nitra a hlasité zaržáni fantazie..."30. V Mahenovom ponímaní sa teda zlievajú hodnotové svety básnika - pevca - vzbúrenca a zbojníka, prototypy „energického, dobrého a zároveň ukrutného" človeka, vyznávajúceho nadovšetko slobodu.

Tvorivý návrat k zbojníckemu hrdinovi Jiří Mahen realizoval aj v o niečo neskoršej zbojníckej povesti pre deti Dvanáct zbojničku a vrána, zaradenej do zbierky rozprávok Co mi liška vyprávěla (1. vyd., 1922) a záujem o zbojnícku tematiku uňho pretrvával prakticky až do posledného dychu. Podla správy Ludvíka Kunderu ${ }^{31}$, v Mahenovej pozostalosti sa našiel projekt poslednej autorovej zamýšlanej zbierky, v ktorej jeden zo spevov mal oživovat zbojníckeho hrdinu Vuka Lopušina „brata Jánošíkovho“, a jeden zase mal byt venovaný Slovensku.

28 Hra bola inscenovaná v tom istom roku (1905) v Uranii a vyvovala, ako píše J. Mourková (1983, s. 42), „sponánni ohlas mezi studentskou mládeži".

29 V hre, ktorá má symbolické vyznanie a exotický kolorit, sa prelínajú viaceré literárne inšpirácie, zliate do zaujímavo vyznievajúceho celku. Autor sa inšpiroval viacerými svetovo známymi velkými dielami európskeho romantizmu, hojne inšpirovaného práve španielskou históriou. Hra si nepochybne zaslúži podrobnejšiu analýzu.

30 MAHEN, Jiří: Máchova poesie a jeji význam, 1910. Citované podla MAHEN, Jiř́i: Za oponou uměni a života. (K. H. Mácha). Praha: Československý spisovatel, 1961, s. 52.

31 KUNDERA, Ludvík: Zpráva o projektu posledni básnické sbirky Jiř́ho Mahena. In: Jiří Mahen - spolutvůrce pokrokové kulturní politiky. (Sborník z konference). Brno: Státní vědecká knihovna, 1983, s. 129-134. 
Určením dôvodov, ktoré Jiř́ího Mahena mohli viesṫ k spracovaniu jánošíkovskej tematiky, sme naznačili autorove inšpiračné zdroje a estetické východiská, a nepriamo aj jeho umelecké (a spoločenské) zámery.

Celkovo možno konštatovat, že Mahenov Janošı je výsledkom kombinácie mnohých inšpiračných zdrojov, v rámci ktorých majú pomerne široké zastúpenie zjednodušené romantické podoby. Autor kombinuje rôznorodé folklórne a literárne motívy a zasadzuje ich do dobrodružného dejového rámca, charakteristického vypätými situáciami, patetickými momentmi a teatrálnostou. Využíva celú škálu topických momentov charakteristických pre romantické spracovania zbojníckej látky, konkrétnejšie pre ich „populárne“ verzie. Ako príklad pars pro toto uvedieme lúbostnú líniu Mahenovej drámy spočívajúcu v príbehu Jánošíkovej lásky k dievčine Anke. Po odchode Jánošíka do hôr sa zbojníkova milá nachádza v neriešitel’nej situácii. Je prenasledovaná zemianskym synom Šandorom a je voči nemu bezbranná, ked’že nemôže počítat s ochrancom. Jej príbeh je drámou v dráme, vyvíja sa a vrcholí v štvrtom dejstve. Šandorov nátlak sa stupňuje a zloduch si Anku prichádza odviest̉ násilím na zámok. Dievčina sa snaží zachránit sa príslubom manželstva seberovnému nápadníkovi Samkovi. V kritickom momente, ked' má byt odvedená na zámok, prichádzajú zbojníci a zachránia ju, pomstiac sa násilníkovi smrtou. Táto dejová zápletka a typy postáv (bezbranná deva z ludu - svojvolný panský násilník - ženích - spravodlivý lud berúci spravodlivost̉ do svojich rúk, v tomto prípade zbojníci) vykazuje zjavné podobnosti s typickým konfliktom španielskych barokových komédiî32.

Historický rámec Mahenovho Janošika je zahmlený a vcelku nepodstatný, hru nemožno považovat za historickú, ale za pseudohistorickú. Slovenský element plní funkciu luudového „exotického“ koloritu a prejavuje sa hlavne v použití krojov, v hudobnej scénickej zložke a v jazykovom spracovaní. O tom, že Mahenov Janošík je „slovenský“ iba „svojím spôsobom“, sa otvorene vyjadril sám autor. Píše, že jeho Janošík (bez „slovenskej“ slabič-

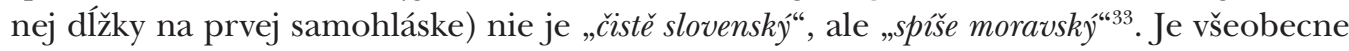
známe, že Mahen sa primkol k sprostredkovanému obrazu Jánošíka a jeho družiny na základe materiálov českého maliara a prozaika Miloša Jiránka, ktorý sa k tejto téme priblížil o čosi prv (grafický cyklus Zbojníci, Dojmy a potulky, 1908). Otvorene sa k tomu priznáva v stati Proč Janošik?: „[Janošík] Zrodil se z Jiränkových Zbojnikư, ze slovenských knižek o Janošikovi, z vyprávěni lidiček kolem Staré Turé a Myjavy... “34. Zaujímavé je Mahenovo „priznanie sa“ k podnetom pochádzajúcim zo „slovenských knižek o Jánošikovi“"35, čím sa vlastne jasne priznáva k inšpirácii kalendárovou, tzv. populárnou literatúrou, ktorá v očiach slovenských kritikov prakticky celkom znemožnila M. Vrbu-Skačanského. Túto inšpiráciu autor pripúšta v matérii lúbostnej zápletky, tvrdiac, že jeho Janošik „přejímá starý kalendárovitý

32 Autorom svetovo najznámejšej drámy vybudovanej na podobnej schéme je opät Lope de Vega. Máme na mysli spoločenskú „komédiu“ zo začiatku 17. storočia Fuenteovejuna (prekl. Ovčí pramen, Vzbúrená dedina).

33 MAHEN, Jiří: Proč Janošik? (1931). Citované podla MAHEN, Jiří: Za oponou uměni a života. (Text Janošik). Praha: Československý spisovatel, 1961, s. 86.

34 Tamže, s. 89.

35 Tamže, s. 86. 
román Janošikovy lásky, jak si ho lid vymyslil“"36, pričom milostná línia je skutočne asi najvzdialenejšia možnej „fantázii l’udu“ (jej podobnost’ s cudzími literárnymi predlohami sme komentovali vyššie).

Treba pritom uznat, že Jiří Mahen sa zaujímal aj o slovenskú literárnu tradíciu, ale v čase písania hry mu táto bola preukázatel’ne neznáma. Začiatkom júna 1909 oslovil s prosbou o poskytnutie materiálov o Jánošíkovi Miloša Jiránka, ktorý mu odpísal: „Slovácká literatura o Jánošikovi je i početne dosti chudá a literárne témeř bezcenná. Jediná seriózni věc je Bottova Smrt’ Jánošíkova [...]. Román o Jánošikovi vyšel začátkem let osmdesátých ve Slovenských pohladech, tuším od Jonáše Beblavého. " Začiatkom augusta sa Jiránkovi Mahen pod'akoval s nadšenou správou, že materiály nepotrebuje, pretože Janošíka má napísaného a je „už s celou věci hotov. “38 Autor si teda skutočne nebol vedomý toho, že by nadviazal na nejakú slovenskú literárnu tradíciu, alebo že by v slovenskej literatúre existovalo čosi hodné pozornosti v súvislosti s jánošíkovskou tematikou. Ked’že jeho sčítanost̉ bola nasmerovaná na domácu (českú) a na (západo-európsku) romantickú literatúru ${ }^{39}$, vedome sa cítil skôr pokračovatel’om romantickej historickej drámy, konkrétne európskej romantickej zbojníckej drámy. Vzhl’adom na časové súradnice však jeho Janošika nemožno označit za romantickú, ale za novoromantickú drámu.

Takáto estetická afiliácia je úplne v súlade s tendenciami v španielskej literatúre (kolíske „zbojníckej komédie“), v ktorej práve „novoromantický prúd“ predstavuje jednu z línií dramatickej tvorby prvých desatročí 20. storočia. Najvýznamnejšími predstavitelmi tohto prúdu sú bratia Manuel Machado (1874-1947) a Antonio Machado (1875-1939), autori zbojníckej drámy Vojvodkyňa z Benameji (La Duquesa de Benamejí, 1932), oživujúcej mýtus romantického zbojníka a využívajúcej všetky toposy romantickej zbojníckej drámy. Ich dramatická tvorba býva odborníkmi označovaná ako modernistická, symbolistická, tradicionalistická či poetická, ale aj ako „novoromantická“40. Bratia Machadovci sa ako dramatici otvorene hlásia k odkazu baroka a romantizmu a ako zdroj inšpirácie hojne využívajú domácu (v ich prípade andalúzsku) l’udovú tradíciu. Obnovu dramatického umenia vidia v návrate $\mathrm{k}$ prostote, jednoduchosti a k všeobecne zrozumitel'nému dramatickému výrazu, ktoré by z divadla urobilo predstavenie atraktívne pre široké vrstvy publika a pôsobiace naň výchovne a oslobodzujúco. Ich poetika je blízka Mahenovmu ,javiskovému lyrizmu“ a jeho ponímaniu spoločenskej funkcie divadla v zmysle slov Štěpána Vlašína, ktorý sa na adresu Jiřího Mahena - dramatika vyjadril takto: „Rád experimentoval, at'

36 Tamže, s. 89.

37 HEK, Jiří - VLAŠÍN, Štěpán: Adresát Jiři Mahen. Praha: Státní nakladatelství krásné literatury a umění, 1964, s. 183.

38 Tamže, s. 185.

39 Ako o oblúbených autoroch sa vyjadruje o K. H. Máchovi aj o Victorovi Hugovi.

40 Pozri GUERRA, Manuel Henri: El teatro de Manuel y Antonio Machado. Madrid: Editorial Mediterráneo, 1966; BAAMONDE, Miguel Ángel: La vocación teatral de Antonio Machado. Madrid: Gredos, 1976; BENHAMAMOUCHE, Fatma: Los hermanos Machado y su producción teatral. In: Verba hispanica. Vol. 3, n ${ }^{\circ} 1$, 1993, s. 27-36; OLIVA, César: Teatro español del siglo XX. Madrid: Editorial Síntesis. 2004; CHICHARRO CHAMORRO, Dámaso: Introducción. El teatro de Manuel y Antonio Machado desde la perspectiva actual. In: MACHADO, Manuel; MACHADO, Antonio: La prima Fernanda. La Duquesa de Benamejí. (Ed. Dámaso Chicharro Chamorro). Madrid: Espasa Calpe, 2006, s. 9-158. 
už razil cestu novému jevištnimu lyrismu, nebo poetistické osvobozené fantazii, ale zároveň vždy chápal dramatickou tvorbu jako nástroj boje o lepši společnost. "41 Mahenova tragédia Janošík sa teda javí ako ekvivalentná k tejto línii novoromantickej zbojníckej drámy.

\section{Záver}

Ako vyplýva z predchádzajúcej reflexie, v slovenskej literatúre existovali zdanlivo dobré predpoklady na vývoj zbojníckej drámy. Symbolika zbojníckeho hrdinu mala predpoklady byt kladne prijímaná a jednoducho dešifrovatel'ná a $\mathrm{k}$ dispozícii boli domáce zdroje inšpirácie v životných príbehoch historických zbojníkov a v bohatej ludovej tradícii. V priebehu 19. storočia sa viacerí slovenskí autori snažili vytvorit zbojnícku drámu, pričom ich pokusy neboli vzhladom na európsku literatúru vôbec oneskorené. Štefan Petruš zareagoval na tendencie (západo)európskej zbojníckej drámy už v dvadsiatych rokoch 19. storočia, jeho pokus však nebol v domácom prostredí priaznivo prijatý, rovnako ako aj neskoršie pokusy jeho nasledovníkov. Generácia štúrovcov neschvalovala preberanie „cudzích“ európskych vzorov a literatúru, ktorá by mala iný ako národno-reprezentatívny a národno-obranný charakter (napríklad zábavný), neuznávala. Ďalším podmieňujúcim faktorom bola orientácia na poéziu ako na dominantný literárny druh. Štúrovská generácia si síce uvedomovala potenciálnu silu drámy a divadelného predstavenia pri šírení ideí, avšak podmienky na rozvoj divadla na Slovensku neboli v 19. storočí ešte dostatočne konsolidované. Pokusy slovenských autorov o vytvorenie domáceho diela na spôsob romantickej zbojníckej drámy sa preto nestretli s pochopením a všetky zostali pre verejnost’ prakticky neznáme.

Prvou divadelnou hrou, v ktorej sa prejavuje česko-slovenské prepojenie (vyšla v Prahe vo vydavatel'stve F. Karabinu), bola smutnohra Miška Vrbu-Skačanského Jánošík z roku 1880. Dielo vzniklo v období, ked' v európskych literatúrach prevládala produkcia populárnej „zjednodušenej“ podoby neskoro-romantickej zbojníckej drámy. Michal Skačanský vytvoril túto divadelnú hru podla vtedajšej módy, avšak domácimi kritikmi bol ako autor prakticky znemožnený. Ak si situáciu porovnáme napríklad so španielskou literatúrou, zistujeme, že v rovnakom čase vznikali divadelné hry vybudované na podobných umeleckých postupoch a vyznačujúce sa podobnou kvalitou, a pritom boli prijímané s nadšením. Túto diametrálne odlišnú recepciu treba chápat tak, že španielska literatúra bola kolískou zbojníckej drámy a „zbojnícky“ dramatický podžáner bol súčastou domácej tradície, na rozdiel od slovenskej literatúry, kde bol programovo odmietaný ako čosi cudzie a škodlivé. Skačanského smutnohra Jánošik je teda „pseudoromantická“ (v zhode s názorom J. Goszczyńskej) vzhl’adom na charakter slovenského romantizmu, ale „plne romantická“ vzhladom na charakter európskej zbojníckej drámy. Z hladiska časového a aj z hladiska poetiky ju možno nazvat drámou „neskororomantickou“. M. Vrbom-Skačanským sa uzatvára prvá fáza vývoja zbojníckej drámy v slovensko-českom priestore, ktorú možno nazvat’ etapou „od preromantických po neskoro-romantické podoby“.

41 VLAŠÍN, Štěpán: Jiři Mahen - spolutviorce pokrokové kulturni politiky (úvodni referát). In: Jiří Mahen - spolutvůrce pokrokové kulturní politiky. (Sborník z konference). Brno: Státní vědecká knihovna, 1983, s. 34. 
Začiatkom 20. storočia sa k slovenským pokusom dramatického spracovania jánošíkovskej tematiky pridružujú české, z ktorých najúspešnejším je dráma Janošík Jiřího Mahena z roku 1910. Pri jej kompozícii sa autor prikláňal k populárnym „kalendárovým“ verziám jánošíkovskej legendy a využil svoje znalosti z oblasti európskej romantickej drámy, pripisujúc slovenskej l’udovej tradícii v jej „čistej“ podobe iba vedlajšiu inšpiračnú funkciu. Predchádzajúce slovenské literárne spracovania mu boli prakticky neznáme ${ }^{42}$. Autor sa zároveň spoliehal na filter, cez ktorý jánošíkovskú tradíciu vnímali českí umelci pred ním (predovšetkým M. Jiránek). Mahenova dráma Janošî, založená na overených literárnych vzoroch, celkovo vychádzala v ústrety českému publiku, pre ktoré bola zamýšlaná. V odhadnutí vkusu a očakávaní tohto publika sa autor nemýlil. Vytvoril atraktívnu hru na spôsob romantickej zbojníckej drámy, ozvláštnenú exotikou slovenskej „životodarnej prostoty“ a zároveň solidarizujúcu s aktuálnym bojom za slobodu národa obývajúceho „krajinu na východ“. Jiří Mahen predstavil drámu tak, aby vyznela ako hold slovenskému hrdinovi a deklaruje to v úvodnom motte-venovaní. Tomuto hrdinovi robí službu tým, že ho „popularizuje“ a „zmedzinárodňuje“. Túto dimenziu postrehla napríklad Ute Roßloffová, ktorá uznáva podiel českých umelcov, zvlášt J. Mahena, na „popularizovani postavy Jánošika. "43 Mahenovo novoromantické spracovanie malo vytvorené prajnejšie podmienky na recepciu než predchádzajúce slovenské drámy a práve úspešnost̉ u publika mu pomohla prekonat’ striezlivý ohlas kritiky, ktorá upozorňovala na estetické a kompozičné nezrovnalosti diela (bratia Čapkovci, F. X. Šalda, Z. Nejedlý a iní).

Mahenov Janošik signalizuje začiatok druhej etapy vývoja zbojníckej drámy, ktorá sa situuje do prvej polovice 20. storočia a vyznačuje sa slovensko-českým prepojením. Jánošíkovská tematika, zvlášt v jej dramatických a aj neskorších filmových podobách, sa v tomto období stáva jedným z prostriedkov česko-slovenského kultúrneho zbližovania.

\section{Literatúra}

BAAMONDE, Miguel Ángel: La vocación teatral de Antonio Machado. Madrid: Gredos, 1976.

BABIAK, Michal: Preromantická dráma Štefana Petruša. In: PETRUŠ, Štefan: Rajnoha, zbojnícky hajtman aneb Začátkové černohrončárských handlov. Bratislava: Národné divadelné centrum, 1998, s. 213-225.

BENHAMAMOUCHE, Fatma: Los hermanos Machado y su producción teatral. In: Verba hispanica. Vol. 3, no 1, 1993, s. 27-36.

CARDINALE, Rosa: El bandolero español entre la leyenda y la vida real. Calas en configuraciones del bandolero en textos paradigmáticos de los siglos XVII-XX. Madrid: Editorial Verbum, 2009.

DIXON, Víctor: Un género en germen: Antonio Roca de Lope y la comedia de bandoleros. In: CLOSE,

42 Bohužial, slovenské romantické dramatické spracovania mu známe byt̉ nemohli, ked’že zásluhou domácej slovenskej kritiky boli odsúdené na dlhodobé zakliatie v rukopisnej forme, ale Mahen nepoznal ani jánošíkovské diela vydané v Prahe v roku 1880, ako vyplýva z korešpondencie s M. Jiránkom z letných mesiacov roku 1909, ked’ pracoval na svojom Janošikovi.

43 RAßLOFF, Ute: Český Jánošik. In: JUNGMANNOVÁ, Lenka (ed.): Česká literatura rozhraní a okraje. Praha: Ústav pro českou literaturu AV ČR, nakladatelství Akropolis, 2010, s. 426. 
Anthony J. - FERNÁNDEZ VALES, Sandra María (koord.): Edad de Oro cantabrigense: Actas del VII Congreso de Asociación Internacional de Hispanistas del Siglo de Oro. Madrid-Franfurkt: Iberoamericana Editorial Vervuert, 2005-2006, s. 189-194.

GARCÍA GONZÁLEZ, Almudena: El bandolero histórico como personaje de comedia en Lope. In: Anuario Lope de Vega. Texto, literatura, cultura. XVIII. 2012, s. 63-79.

GOSZCZYŃSKA, Joanna: Mýtus o Jánošikovi vo folklóre a slovenskej literatúre 19. storočia. Bratislava: Juga, 2003. (Pol'ský originál Mit Janosika w folklorze a literaturze slowiackiej XIX wieku. Warszawa: Uniwersytet Warszawski, 2001).

GUERRA, Manuel Henri: El teatro de Manuel y Antonio Machado. Madrid: Editorial Mediterráneo, 1966.

HEK, Jiří - VLAŠÍN, Štěpán: Adresát Jiři Mahen. Praha: Státní nakladatelství krásné literatury a umění, 1964.

CHICHARRO CHAMORRO, Dámaso: Introducción. El teatro de Manuel y Antonio Machado desde la perspectiva actual. In: MACHADO, Manuel - MACHADO, Antonio: La prima Fernanda. La Duquesa de Benamejí. Ed. Dámaso Chicharro Chamorro. Madrid: Espasa Calpe, 2006, s. 9-158.

KUNDERA, Ludvík: Zpráva o projektu posledni básnické sbirky Jiř́ho Mahena. In: Jiří Mahen - spolutvůrce pokrokové kulturní politiky. (Sborník z konference). Brno: Státní vědecká knihovna, 1983, s. 129-134.

MACHADO, Manuel - MACHADO, Antonio: La prima Fernanda. La Duquesa de Benameji. Ed. Dámaso Chicharro Chamorro. Madrid: Espasa Calpe, 2006.

MAHEN, Jiří: Za oponou uměni a života. Praha: Československý spisovatel, 1961.

MAHEN, Jiřrí: Jánošik. In: MAHEN, Jiří: Jánošík, Ulička odvahy, Nasreddin. Praha: Státní nakladatelství krásné literatury a umění, 1962, s. 7-125.

MOURKOVÁ, Jarmila: K pramenưm osobnosti Jiřiho Mahena v jeho literárních počátcích. In: Jiří Mahen - spolutvůrce pokrokové kulturní politiky. (Sborník z konference). Brno: Státní vědecká knihovna, 1983, s. 39-47.

OLIVA, César: Teatro español del siglo XX. Madrid: Editorial Síntesis, 2004.

PETRUŠ, Štefan: Rajnoha, zbojnicky hajtman aneb Začátkové černohrončárských handlov, 1823. Textová úprava Dana Lehutová. Bratislava: Národné divadelné centrum, 1998.

RAßLOFF, Ute: Český Jánošík. In: JUNGMANNOVÁ, Lenka (ed.): Česká literatura rozhraní a okraje. Praha: Ústav pro českou literaturu AV ČR, nakladatelství Akropolis, 2010, s. 419-435.

TVRDOŇ, Jozef: Jiř́ Mahen a Slovensko. In: Krásy Slovenska 37, 1960, č. 9, s. 341-344.

VLAŠÍN, Štěpán: Doslov. In: MAHEN, Jiří: Jánošík, Ulička odvahy, Nasreddin. Praha: Státní nakladatelství krásné literatury a umění, 1962, s. 301-308.

VLAŠÍN, Štěpán: Jiřr Mahen - spolutviorce pokrokové kulturni politiky (úvodni referát). In: Jiří Mahen spolutvůrce pokrokové kulturní politiky. (Sborník z konference). Brno: Státní vědecká knihovna, 1983, s. 13-36.

ZELENKOVÁ, Anna - POKORNÝ, Milan: Knižni slovacika v českých nakladatelstvích 1918-1925. In: POSPÍŠIL, Ivo - ZELENKA, Miloš (eds.): Česko-slovenské vztahy, Evropa a svět. Brno: Ústav slavistiky FF MU, 2004, s. 123-134. 
ŻABSKI, Tadeusz: Proza jarmarczna XIX wieku: próba systematyki gatunkowej. Wrocław: Wydawnictvo Uniwersytetu Wrocławskiego, 1993.

doc. Mgr. Renáta Bojničanová, PhD.

Katedra románskych jazykov a literatúr

Pedagogická fakulta, Univerzita Komenského v Bratislave

Račianska 59, 813 34, Bratislava, Slovensko

bojnicanova@fedu.uniba.sk 
